\title{
Educational Issues of Muslim Migrants in Japan
}

\author{
Shiro Ito \\ Ph.D. Student, Department of Sociology, College of Social Sciences and Philosophy \\ University of the Philippines, Diliman, Philippines \\ E-mail: shiro.ito@up.edu.ph
}

$\begin{array}{lcc}\text { Received: April 27, } 2011 & \text { Accepted: August 4, } 2011 \quad \text { Published: January 1, } 2012 \\ \text { doi:10.5539/ass.v8n1p104 } & \text { URL: http://dx.doi.org/10.5539/ass.v8n1p104 }\end{array}$

\begin{abstract}
This report analyzes educational interests of Muslim immigrant families in Japan. It explores the kind of education the Muslim people want for their children and the educational issues they face. The research used data from qualitative interviews conducted by the author, who visited several mosques in Tokyo to interview more than 50 families in 2001. One of the worries and hopes that foreign Muslims in Japan possess concerns their children's education. This research found that these parents worry about Japanese cultural influence on their children. Some Muslim parents in Japan feel that it is necessary to build Muslim schools where they can maintain consistency among their home, their school, and their community.
\end{abstract}

Keywords: Muslim, Ethnicity, Education, School, Qualitative, Japan

\section{Background}

In the late 1980s, the labor shortage and the high value of the yen brought many immigrants to Japan. As many of these immigrants established residence in Japan, Muslim communities in Japan developed. Some of these immigrants possessed business or professional skills and the majority were laborers from India, Pakistan, Iran, Bangladesh, Sri Lanka, Thailand, and the Philippines (Miyata, 2000). Many immigrants from Muslim countries worshipped in mosques. "Especially for Muslim workers who engage in physical labor, Muslim religious activities provide mental satisfaction and create the bond with other fellow Muslims" (Miyata, 2000, p. 216).

There are no statistics on the number of foreign Muslims in Japan. The Ministry of Internal Affairs and Communications identifies citizens and the demographics of the country, but religion is not a criterion in the statistics. The mosques in Japan also do not keep demographic records of their congregations. According to the Islamic Center Japan, the Muslim population in Japan is approximately 200,000, less than $0.2 \%$ of Japan's total population. Among that number, about 50,000 are Japanese-born citizens who converted to Islam (Miyata, 2000).

This report analyzes educational interests of the Muslim immigrant families in Japan. This report explores the kind of education the Muslim people want for their children and the educational issues they face. The research will use data from qualitative interviews conducted by the author, who visited several mosques in Tokyo to interview more than 50 families in 2001.

\section{Islamic Education}

One of the worries and hopes foreign Muslims in Japan maintain is about their children's education. "In Japan, there is no religious school for Islamic religious education, so Muslims have to rely on private instruction. Such lack of religious education troubles those faithful Muslims with solving the dilemma of how to educate their offspring" (Miyata, 2000, p. 215).

In this, the most important part of Islamic religious education is the study of the Koran. The Koran's teachings cannot be separated from the daily life of Muslims. Muslim children must first learn about the Five Pillars of Islam, including the proper way of worship and the memorization of the Koran. In Muslim countries, Koran study is conducted in a small house of worship or a mosque. There, students gather around a teacher to worship together, learn Arabic, and/or how to read the Koran. They also learn the rules of worship and Islamic belief and theory (Nishino, 1994).

Memorization of the Koran is very important and a means of measuring not just a person's devotion but also the 
quality of his or her education. Therefore, it is necessary for education to begin in early childhood. There is a movement among the Muslims in Japan to teach Islamic principles in kindergarten. The traditional Koran study starts with learning the Arabic alphabet. Then, the children learn how to read short passages of the Koran before starting to memorize them (Nishino, 1994).

In addition, there are sekolahs (schools) and madrasahs (religious schools). Devout Muslims do not believe that the regular schools provide enough religious education. Some parents send their children to a madrasah because of the higher quality of Islamic education. Many families send their kids to a madrasah to learn Islamic morals (Nishino, 1994).

Considering the values held by Muslim parents, there is a huge gap between Japanese schools and madrasah education. For many parents, Islamic education is a priority. From the Muslim point of view, the purpose of education is to contribute to God and students should learn Arabic to read the Koran and understand its laws.

\subsection{Educational Outlook of Muslim Parents in Japan}

While many Muslims send their children to Japanese public schools, many of them have negative opinions about those schools because of the lack of Islamic education. The most common opinion found during the research is that it is difficult to maintain the Islamic lifestyle in the Japanese school system. The following are some cases.

Mr. A., male, from Pakistan: "I have four children, but they all go to a private elementary school in Pakistan. I wish to send them to the university. I would like to send them to a school in Japan, but it is important that they receive the Islamic education. I think it is very hard in Japan. So, I prefer the school in Pakistan."

Mr. H., male, 20s, from Turkey, married to a Japanese woman: "We should have our children learn morals based on Islam. So, I plan to send them to study in an Islamic country."

Mr. K., male, 30s, from Pakistan: “The Japanese environment is not good for our children's education. They will be discriminated against in Japan. I want to send them to Islamic school, then elementary school, then university, but since there is no such school now, I want to send them to an international school in Japan."

Mr. T., male, 30s, from Pakistan: "I don't think Japan is good because of the food issue. It is important to eat Islamic food. I also want my child to receive...education based on Islam. I think it is very hard in Japan. I heard that there are international schools in Tokyo, but it is far from my home, so it is not convenient. It would not be good because it is not an Islamic school. So I prefer schools in Pakistan."

Mr. B., male, 30s, from Ghana, married to a Japanese woman, came to Japan in 1997: "I wanted to be a diplomat before I came to Japan. But I started feeling the bureaucrats were corrupted, and I gave it up. I feel sorry for many poor people in my country. My current future goal is to work for poor people. I am married to a Japanese woman and have one child. I think we will have educational problems. I have not been to Japanese school so I don't know about it very well, but it's better not to choose a Japanese school because of the bullying problem that migrants' children face. I don't think they teach spiritual things in Japanese schools. However, it is very good to learn math and science. I have a brother in UK; I can send my child there."

Ms. F., female, 30s, from Pakistan, living in Japan for ten years, and Ms. A., also in her 30s from Pakistan, has been in Japan for five years. Both came to Japan with their husbands, who were making business trips. They have the following opinion about Japanese school systems: "We try to attend the gatherings, such as PTA meetings of school. Because of the language barrier, we can't communicate with other Japanese mothers. We want to have our children receive education based on Islam, but since there is no such school in Japan, we have no choice but to send them to a public school. To be honest, we don't want our children to go to a Japanese school because of cultural influence."

Mr. H., male, 30s, from Pakistan: "About 10 years ago, there were not so many foreign children, and there was a lot of bullying going on. For the same reason, mixed children were beaten. So, some children learned Karate to protect themselves. However, recently, there are more foreign kids and schools tend to understand issues. As for the education of children for the future, there used to be a trend to go back to the home country so that...children can receive...education there. But these days, migrant families tend to try their best in Japan."

\subsection{Educational Value of the Muslim Volunteer Teachers in Japan}

In light of the educational values of Muslims in Japan - clearly wishing to educate their children in the Islamic way-I interviewed Muslim volunteer teachers in mosques. The following are some cases.

Mr. S., male, 30s, from Ghana, Muslim teacher who volunteers in a mosque for three hours on the weekends: "The most important thing for the children is to learn the Islamic rules and live according to these rules. For this... is necessary to learn the Koran. It is better to start the study when the child is young, like three years old." 
Mr. M., male, 30s, from Pakistan, single, college graduate who volunteer teaches the Koran and Arabic at the mosque in Tokyo: "In Japan there are not so many places to teach Islam to the children. There are places just to teach Arabic but not so many places to teach Islam. For children, Islamic education is necessary because Islam guarantees the child's growth and better life. Islamic life prepares one for the next life. The time to live is short and soon death will come. It is a relief that you are prepared for the life after death. We are not working for money, but we are teaching to get a reward...after death. As for the reward, the act of teaching has an effect to increase the reward from God. I am happy as long as I can live according to the Islamic way of life. If Japanese people learn about Islam, the better life will be guaranteed for them in this life and after death."

Mr. A., male, 50s, from Pakistan, married, college graduate, with family in Japan and Pakistan, realizes the necessity to construct mosques and contributes to its establishment: "My dream is to build an Islamic school. I would like to build a school where we can teach up to 2 nd or 3 rd grades. There are various standards to build a school in Japan. For example, they need a school ground and so on. In the end, I hope to teach up to the 6th grade. Then, I want to establish a system that allows those who graduate from this Islamic school to advance to Japanese junior high school. For that, I would like to cooperate with Japanese schools. For example, I would like to ask Japanese teachers to teach mathematics and science. In this field, we need teachers who can teach subjects other than Islam. However, I don't think there are many Japanese teachers who believe in Islam. I want to build a school where the Muslim teachers teache Islam for children. There are two types of foreign Muslims. One aims to remain in Japan, and the other wishes to return to his homeland. There are still more people who wish to return after staying in Japan for a while, but there are more and more people who wish to remain in Japan. Most of those people have a Japanese wife. So many people wish to live in Japan. There are strong needs to build Islamic schools in Japan. The school means a lot to the families who wish to remain in Japan. For those who plan to return, I want to establish a system where the children can learn at affiliate schools overseas and obtain the international diploma."

Mr. A., male, 30s, from Pakistan, married, college graduate, with family in Japan and Pakistan, teaches Arabic and the Koran to children at the mosque: "It is very important for people to learn Islam. By teaching, you can feel happy and satisfied. I came to Japan for work. My family is poor so I want to help them. However, my dream is not to make money but live through the Islamic path and to teach Islam to everyone. Japan has so many things but not peace of mind. The Japanese need to realize that human beings cannot do anything by themselves. Current Japanese morale is not good. In the past they had better morale. I want to teach Japanese people about Islam. Japanese know too little about Islam. Generally, most Japanese people are nice. However, nowadays, Japanese people are too much influenced by Europe and the U.S. I admire the traditional Japanese value in the past, but how about now?"

\section{Consideration and Conclusion}

We have seen the educational values of Muslim immigrants through interviews. The interviewees seem to agree that some of them do not want to send their children to Japanese schools. The "benefit" of having children learn at an Islamic school is being able to prevent them from being influenced by non-Islamic lifestyles or other religions. Parents wish to minimize the cultural influence on their children. Muslim parents are worried that their children will receive influences and ideas from contemporary Japanese youth culture. The parents can take full advantage of the support from the mosque to educate their children as Muslims. For example, children can learn about life after death, heaven, and hell. If what they learn at home, what they learn from school, and what they learn through daily contact with friends are not consistent, they will experience a psychological conflict. Therefore, Muslim parents in Japan feel that it is necessary to build Muslim schools where they can maintain consistency among their home, their education, and their community.

\section{Acknowledgements}

I would like to thank all of the respondents for their contribution to this study.

\section{References}

Miyata, O. (2000). Islam Power (in Japanese). Tokyo: Koudansya.

Nishino, S. (1994). Islamic Education in Indonesia (in Japanese). Tokyo: Keisou syobo.

Sakuma, T. (1998). A changing multiracial nation United Kingdom (in Japanese). Tokyo: Akashi syoten. 